\title{
Migration Policy of the Regions of the Republic of Kazakhstan: Socio-political Mechanisms of Easing the Interethnic Tension
}

\author{
Gulsara Madanievna Kappassova ${ }^{+*}$
}

\section{Abstract}

A change in the ethnic structure of the population is observed in the Republic of Kazakhstan, which is described by ethnic and cultural diversity. The current situation in the Republic of Kazakhstan has been analysed based on the author's methodology for the quantitative assessment of interethnic tension. The author outlined a set of measures to stabilise interethnic relations, strengthen mutual understanding between citizens of various nationalities, and prevent interethnic conflicts in the Republic of Kazakhstan.

Keywords: ethnic tension, migration, proneness to conflict, stabilisation, interethnic relations, tolerance, civil and ethnic identity, Republic of Kazakhstan

\footnotetext{
${ }^{\dagger}$ S. Toraighyrov Pavlodar State University, 140008, Republic of Kazakhstan, Pavlodar, Lomov St., 64, Email: gulsara.dyusembekova@mail.ru

* Corresponding Author

(C) 2018 Kappassova. This is an Open Access article distributed under the terms of the Creative Commons Attribution License (http://creativecommons.org/licenses/by/2.0), which permits unrestricted use, distribution, and reproduction in any medium, provided the original work is properly cited.
} 


\section{Introduction}

Back in 1990, with the adoption of the Declaration on State Sovereignty of the Republic of Kazakhstan, the task of strengthening the national dignity of the Kazakh nation and other nationalities living in Kazakhstan was set as a priority task for the government.

Among the states of the post-Soviet space, the Republic of Kazakhstan is described as a country with the most stable political system and public stability (Rustembekova and Amandykova, 2013; Assyltaeva et al. 2014).

Ethnic conflicts and wars in neighbouring countries of the near abroad about Kazakhstan (Kyrgyzstan, Uzbekistan, Tajikistan and Russia) resulted in enormous economic, political, humanitarian problems for people and had a negative impact on the development of these independent countries. Some conflicts on the territory of the post-Soviet countries (for example, in the Republic of Azerbaijan, Armenia) still cannot find any political, legal solution, threatening to result in further intercultural and interstate conflicts (Mukhamedzhanova 2011).

Unlike the neighbouring countries, in Kazakhstan, international conflicts are not expressly manifested while interethnic stress level remains rather low. At the same time, the studies of the interethnic situation in Kazakhstan reveal that there are risks associated with high ethnic conflict potential and a high degree of dissatisfaction with the cultural and language-specific needs of the members of society (Nurgaliyeva 2013).

Migration policy of the government is one of the factors that have an impact on the ethnic composition of the population and the stability of the interethnic situation in the country. The coexistence of various ethnic groups on the common territory in a multicultural country such as the Republic of Kazakhstan is regarded as a relevant field of diverse scientific research. The applied problems of scientific research in this field include developing the efficient mechanisms for easing interethnic tension in the country. The conceptual issues of ethnocultural development and impact of migration on the ethnic composition of the population are discussed in the works of D.K. Rustembekova and S.K. Amandykova (2014), A.M. Borangaliyev (2010), E.Yu. Sadovskaya (2001), G.G. Nurgalieva (2013), D.Sh. Mukhamedzhanova (2011), S.V. Kharchenko (2014), S.D. Gurieva (2010), N.I. Yesimhanova (2014), Zh.U. Kydyralina (2012), P.P. Lisitsyn (2017), D. G. Papadimetriou and M. Sampson (2011), T.P. Titova (2015), etc.

Most of the studies on the issues of interethnic relations are based on the study of public opinion. A significant part of the empirical information on intercultural relations within certain regions comes from holding opinion polls. The assessment of the current migration and the intercultural situation is carried out mainly by a descriptive method, which not only provides a collective idea of the object of the study but also creates a foundation for constructing more complex models of analysis.

Problems of quantitative assessment of interethnic stability within the country become especially acute for the Republic of Kazakhstan as a state with a complex ethnic, linguistic and religious composition in the context of rising migration processes, complicating the geopolitical situation, and aggravating national proneness to conflict in many regions of the world. For example, using the score-index assessment method can ensure an objective assessment of the current interethnic situation in the region and make efficient decisions to prevent intergroup conflicts and ease social and political tensions.

At the same time, it must be noted that such studies face a methodological problem: so far, there are no common scientific approaches to the definition of such a concept as "interethnic tension", nor there are any methodological approaches to its quantitative analysis.

The goal of this article is to develop methodological approaches to the quantitative 
assessment of the current situation in the field of nation building and interethnic processes. For this, the following tasks have been accomplished within this study:

- To present the author's methodology for rapid assessment of the current interethnic situation;

- To carry out an analysis of the ethnic structure and its change in the Republic of Kazakhstan;

- To assess the current interethnic situation in the Republic of Kazakhstan;

- To identify promising mechanisms for managing interethnic relations and creating a system of preventing intergroup conflicts.

The desktop study results in the presentation of the material on the issues of the methodology for the quantitative assessment of the current interethnic situation. The empirical stage of the study includes four sections:

The first section analyses the ethnic structure of the regions of the Republic of Kazakhstan and the impact of migration processes on the change in the number of certain ethnic groups of the Republic of Kazakhstan.

The second section contains the practical use of the proposed methodology for assessment of the current interethnic situation in the Republic of Kazakhstan. The conducted analysis results in the calculation of the index of interethnic tension, which makes it possible to compare its values across the regions of the Republic of Kazakhstan.

The most relevant problems in the context of interethnic relations in the Republic of Kazakhstan are discussed in the third section.

The fourth section contains an overview of perspective areas of the state policy on strengthening the civil tolerance and prevention of interethnic conflicts in the Republic of Kazakhstan.

The practical relevance of this study lies in the fact that its results can be used to predict the development of the interethnic situation and to develop the national policy of a multiethnic state such as Kazakhstan.

\section{Literature Review}

In this study, a review of the works by domestic and foreign authors has been undertaken, which has enabled to compare the theoretical concepts and methodological issues of studying the nature and characteristics of conflicts among ethnic groups. The topic of the correlation and interaction of ethnic communities and the problems of ethnicity in multinational countries attracted the attention of the researchers in the 1990s.

A huge number of materials on ethnic problems in the territory of the former Soviet Union were prepared by V. Tishkov, a doctor of historical and political science, Director of the Institute of Ethnology and Physical Anthropology of the Russian Academy of Sciences. In his monograph entitled Ethnicity, nationalism and conflict in and after the Soviet Union (Tishkov 1997), the author reveals the methodological approaches to understanding the phenomenon of ethnicity in the modern world with an emphasis on postSoviet theory and social practice.

Tishkov argues that the Soviet regime consciously built an ethnonational identity to create a state based on ethnic principles. His "success" in creating powerful ethnic elites and nationalist ideology ultimately played an important role in the disintegration of the Soviet Union. This work has become one of the first studies containing proposals on political strategies and mechanisms for overcoming interethnic tensions and conflicts in the postSoviet space.

Since independence was declared in 1991, diversity and tolerance became the core of Kazakhstan's national identity. Studying the politics of identity, social transformations, social movements, anti-Americanism and authoritarianism with a focus on the ex-USSR, particularly in Central Asia, Edward Schatz, a professor of political science at the University of Toronto, noted that Kazakhstan had an interesting formation of a new state. Here, 
titular ethnos have become a minority (Schatz 2000).

The construction of a single nation in the country of two large ethnic groups (the Russians and the Kazakhs) with the opposite relationship of language proficiency (more ethnic Kazakhs, with the majority of the Russian-speaking population) is an ambiguous and contradictory process (Melich and Adibayeva 2014).

After the collapse of the Soviet Union, the former Republics faced the problem of state/national identification and language became the most important tool in identifying new independent states and countries (Smagulova 2006). One of the major problems for the leading countries was the consolidation of new nations, the satisfaction of the conflicting interests of various ethnic groups, and the observance of international requirements concerning the rights of minorities.

Special attention of political scientists, sociologists, and philosophers are given to the topic of tolerance of the Kazakh society. According to the researchers, tolerance increases the ability of the ethnic group to adapt to the world around them and is one of the main factors of stability and sustainable development of society (Aubakirova et al. 2016). In times of numerous threats to human existence, such as global terrorism, religious intolerance, ethnic conflicts, understanding, and materialisation of tolerance are important for survival.

\section{Methods}

A study is suggested to accomplish these tasks, which involves collecting information on the national and ethnic composition of certain territories of the Republic of Kazakhstan, analysing documents and processing secondary data obtained from open sources.
The figures of state statistics and the findings of opinion polls of state bodies and public associations of the Republic of Kazakhstan, such as the Center for Social and Political Studies "Strategy", the Kazakhstan Institute for Strategic Studies (KISS), the Institute for Political Research of the Republic of Kazakhstan (IPR), etc. served as the informational background of the study.

The theoretical development of the Kazakh and foreign scientists, along with some empirical works carried out in this area, were the main methodological base of the study.

B.M. Ekkel's mosaic index has been used to assess the ethnic structure of the certain territories of the Republic of Kazakhstan, which is calculated using the following formula:

A study is suggested to accomplish these tasks, which involves collecting information on the national and ethnic composition of certain territories of the Republic of Kazakhstan, analysing documents and processing secondary data obtained from open sources.

The figures of state statistics and the findings of opinion polls of state bodies and public associations of the Republic of Kazakhstan, such as the Center for Social and Political Studies "Strategy", the Kazakhstan Institute for Strategic Studies (KISS), the Institute for Political Research of the Republic of Kazakhstan (IPR), etc. served as the informational background of the study.

The theoretical development of the Kazakh and foreign scientists, along with some empirical works carried out in this area, were the main methodological base of the study.

B.M. Ekkel's mosaic index has been used to assess the ethnic structure of the certain territories of the Republic of Kazakhstan, which is calculated using the following formula:

$$
P=\sum_{i=1}^{m} \pi_{i}\left(1-\pi_{i}\right)
$$


Where $P$ is the mosaic index of the ethnic structure of the population;

$M$ is the number of ethnic groups in the region;

$\pi_{i}$ is the share of the $\mathrm{i}$-th ethnic group in the entire population.

The higher the mosaic index, the more diverse the ethnic composition of the territory.

The proposed methodology for assessing the current interethnic situation in the Republic of Kazakhstan relies on the definition of an integrated assessment indicator - the Index of Ethnic Tension ( $\left.\mathrm{I}_{\mathrm{ET}}\right)$.

A quantitative method was used to collect primary information. Since the official statistics is insufficient for the objective assessment of the interethnic situation, the main source of data was the opinion poll. This poll titled On the state of ethnic cohesion in the Republic of Kazakhstan was conducted by a group of experts from the Bureau of Express Monitoring of Public Opinion DEMOSCOPE from 15 to 23 August 2016 (Bureau of Express Monitoring of Public Opinion DEMOSCOPE, n. d.).

An opinion poll as the most popular quantitative method of collecting primary information has certain limitations, as its results are based on the subjective opinion of the respondents. At the same time, an objective rationale for choosing this method of

$$
\mathrm{I}_{\mathrm{ET}}=\overline{\sum_{1}^{n} r_{l} * P_{l}}
$$

Where $n$ is the number of indicators of the assessment of the interethnic situation;

$r_{i}$ is the share of the respondents who selected this option;

$P i$ is the score assigned to this option.

The results are interpreted using the following scale:

- 1 to 2 - the level of interethnic tension is the lowest, the risk of interethnic conflicts is negligible;

- 2 to 3 - the level of tension is low, cases of individual ethnic conflicts and small nationalistic actions (up to 1,000 people) are unlikely but possible collecting primary information is its successful use in cases when obtaining information for the study in another way is difficult or not easily possible.

The sample volume was 3,192 people from Astana, Almaty and all 14 regional centres of Kazakhstan, of which $69 \%$ were women, and $31 \%$ were men. The age structure of the respondents was divided as follows: more than $40 \%$ of respondents were young people aged $18-29,27 \%$ of respondents referred to the age group of 30-39, the rest were older than 40. The maximum size of the statistical error for this sample with a probability of $95 \%$ did not exceed $1.75 \%$.

Survey methods included a standardised phone $(2,027$ people) and online interview $(1,165$ people). A checklist was prepared in order to conduct a standardised interview and reduce unintended mistakes of the respondents, which was a questionnaire with closed-type questions.

The scaling procedure was used to bring quality characteristics and quantitative indicators to a standard form. Each of the indicators was assigned a score on a 5-point scale, where 1 was a low level of interethnic tension.

The index of ethnic tension $\mathrm{I}_{\mathrm{ET}}$ is calculated using the following formula:

- 3 to 4 - the level of tension is average; there is a risk of individual cases of ethnic conflicts or nationalist actions

- 4 to 5 - the high level of interethnic tension, conflicts are unavoidable, mass nationalist actions are possible

\section{Ethnic Structure of the Republic of Kazakhstan}

According to the State Statistics Committee of the Republic of Kazakhstan, as of 01 January 2016, the population of Kazakhstan amounted to 17,670.6 thousand people (Statistics Committee of the Ministry of National Economy of the Republic of Kazakhstan). Kazakhstan belongs to regions with a high degree of ethnic diversity, despite the fact that the overwhelming majority $(66.5 \%)$ of the 
population are representatives of one ethnic group - the Kazakhs.

Representatives of 18 nationalities reside on the territory of the state today. Aside from the Kazakhs, the largest ethnic groups are the Russians $(3,644.5$ thousand people, or $20.6 \%$ of the total population of the country) and the
Uzbeks (548.8 thousand people or $3.1 \%$ of the total population).

The change in the population size of the most numerous ethnic groups of the Republic of Kazakhstan is described by the region using the following data (Table 1).

\begin{tabular}{|c|c|c|c|c|c|c|}
\hline \multirow[t]{2}{*}{ Nationality } & \multicolumn{2}{|c|}{1989} & \multicolumn{2}{|c|}{2009} & \multicolumn{2}{|c|}{ 01.01.2016 } \\
\hline & People & $\begin{array}{c}\text { Specific } \\
\text { weight in } \\
\text { total } \\
\text { number }\end{array}$ & People & $\begin{array}{c}\text { Specific } \\
\text { weight in } \\
\text { total } \\
\text { number }\end{array}$ & People & $\begin{array}{l}\text { Specific } \\
\text { weight in } \\
\text { total } \\
\text { number }\end{array}$ \\
\hline Kazakhs & $6,534,616$ & $39.7 \%$ & $\begin{array}{l}10,096,76 \\
3\end{array}$ & $63.1 \%$ & $\begin{array}{l}11,748,17 \\
9\end{array}$ & $66.5 \%$ \\
\hline Russians & $6,227,549$ & $37.8 \%$ & $3,793,764$ & $23.7 \%$ & $3,644,529$ & $20.6 \%$ \\
\hline Uzbeks & 332,017 & $2.0 \%$ & 456,997 & $2.9 \%$ & 548,841 & $3.1 \%$ \\
\hline Ukrainians & 896,240 & $5.4 \%$ & 333,031 & $2.1 \%$ & 289,724 & $1.6 \%$ \\
\hline Uighurs & 185,301 & $1.1 \%$ & 224,713 & $1.4 \%$ & 256,295 & $1.5 \%$ \\
\hline Tatars & 327,982 & $2.0 \%$ & 204,229 & $1.3 \%$ & 202,934 & $1.1 \%$ \\
\hline Germans & 957,518 & $5.8 \%$ & 178,409 & $1.1 \%$ & 181,754 & $1.0 \%$ \\
\hline Turks & 49,567 & $0.3 \%$ & 97,015 & $0.6 \%$ & 107,944 & $0.6 \%$ \\
\hline Koreans & 103,315 & $0.6 \%$ & 100,385 & $0.6 \%$ & 107,169 & $0.6 \%$ \\
\hline Azerbaijanis & 90,083 & $0.5 \%$ & 85,292 & $0.5 \%$ & 103,514 & $0.6 \%$ \\
\hline Dungans & 30,165 & $0.2 \%$ & 51,944 & $0.3 \%$ & 66,209 & $0.4 \%$ \\
\hline Belarusians & 182,601 & $1.1 \%$ & 66,476 & $0.4 \%$ & 58,062 & $0.3 \%$ \\
\hline Tajiks & 25,514 & $0.2 \%$ & 36,277 & $0.2 \%$ & 44,738 & $0.3 \%$ \\
\hline Kurds & 25,425 & $0.2 \%$ & 38,325 & $0.2 \%$ & 43,974 & $0.2 \%$ \\
\hline Chechens & 49,507 & $0.3 \%$ & 31,431 & $0.2 \%$ & 32,695 & $0.2 \%$ \\
\hline Poles & 59,956 & $0.4 \%$ & 34,057 & $0.2 \%$ & 31,938 & $0.2 \%$ \\
\hline Others & 387,108 & $2.4 \%$ & 180,489 & $1.1 \%$ & 202,080 & $1.1 \%$ \\
\hline Total & $\begin{array}{l}16,464,46 \\
4\end{array}$ & $100.0 \%$ & $\begin{array}{l}16,009,59 \\
7\end{array}$ & $100.0 \%$ & $\begin{array}{l}17,670,57 \\
9\end{array}$ & $100.0 \%$ \\
\hline
\end{tabular}

Source: Collected by the author (Collection of International and National Documents on the Issues of Combating Trafficking in Persons, 2011)

The average indicator of ethnic mosaic of the population in the Republic of Kazakhstan was 0.513 as of the beginning of 2016. The index of ethnic mosaic for the Republic of Kazakhstan as of the beginning of 2016 is shown in Figure 1.

Analysis of the index of ethnic mosaic allows identifying several centres of multiethnicity on the territory of the Republic of Kazakhstan, from which further settling of many people occurs.
The first multinational area is the northern part of the Republic of Kazakhstan (the Kostanay, Akmola, North Caucasus, Pavlodar regions). The share of Slavic ethnic groups is quite high there, which is largely explained by the forced eviction of Poles and Germans from the USSR in the 30s50 s of the XXth century. Currently, $32.3 \%$ of Russians, $58.5 \%$ of Ukrainians, $52.6 \%$ of Germans, $59.4 \%$ of Belarusians and $71.1 \%$ of Poles of the total living in Kazakhstan are residing on the territory of the Northern Kazakhstan. 
The second multinational area is the Karaganda and East Kazakhstan regions, as well as AlmaAta. About $41 \%$ of the Russian population lives there.

On the contrary, monoethnic areas such as Kyzylorda, Mangistau and Atyrau are described by the smallest values of the index of ethnic mosaic, where the ethnic group of the Kazakhs amounts to $96 \%, 90.3 \%$ and $92.1 \%$, respectively.

Since the acquisition of the independence by the Republic of Kazakhstan, its ethnic structure has undergone significant changes. Active migration processes have an immediate impact on the demographic and territorial positions of the ethnic groups of the Republic of Kazakhstan.

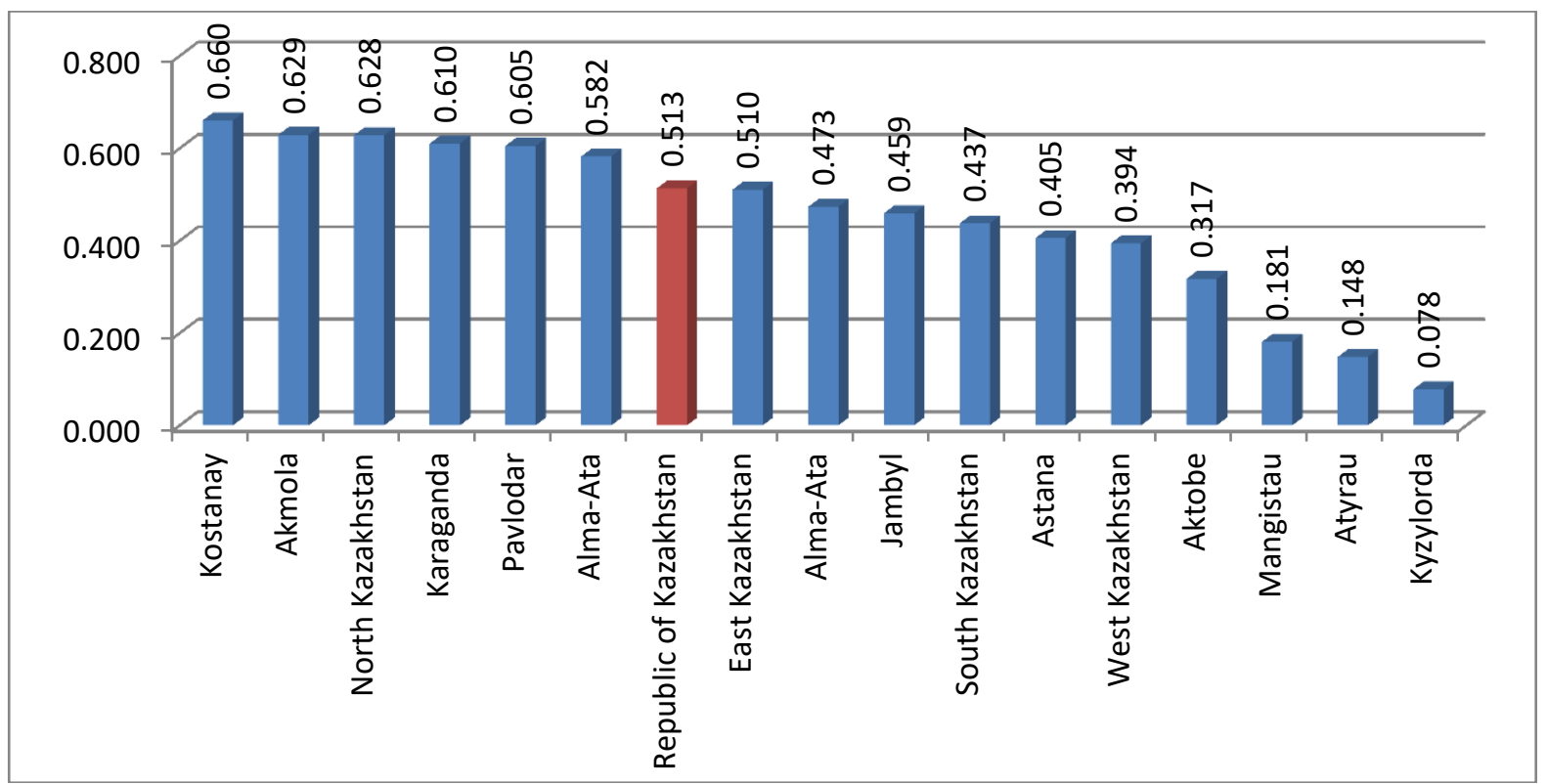

Figure 1: Index of Ethnic Mosaic for the Regions of the Republic of Kazakhstan

\section{Source: Collected by the author}

Active migration is understood as a dynamic change in the flows of migrants due to a voluntary change of residence of a certain part of the population (the definition was formulated by the author of the article).

It is known that the intensity of migration processes directly depends on many external and internal factors and is subject to certain laws formulated by E. Ravenstein (1885):

- migration mainly occurs over short distances;

- the most attractive from the point of view of resettlement are large territorial centres;

- each positive flow corresponds to its negative flow of migrants;

- the growth of large cities is largely influenced by migration, rather than natural population growth;

- development of industry and trade increases the scale of migration.
According to the UN data (United Nations, Department of Economic and Social Affairs, International Migration Report, 2015), there are more than 3.5 million migrants of all categories (including the repatriated Kazakhs, labour migration, migration for personal reasons and exchange) living in the country. This is $20 \%$ of the population of Kazakhstan, equal to 17.5 million people in 2015 (World Bank statistics for 2015).

The entry migration flow is formed from the citizens of Uzbekistan, the Russian Federation, and China (Bulletin of the Committee on Statistics of the Ministry of National Economy of the Republic of Kazakhstan). Priority destinations of the emigration flow are Russia, Germany, Belarus and Uzbekistan. Migration flows of the largest ethnic groups of the Republic of Kazakhstan following the results of 2015 are presented in Table 2. 


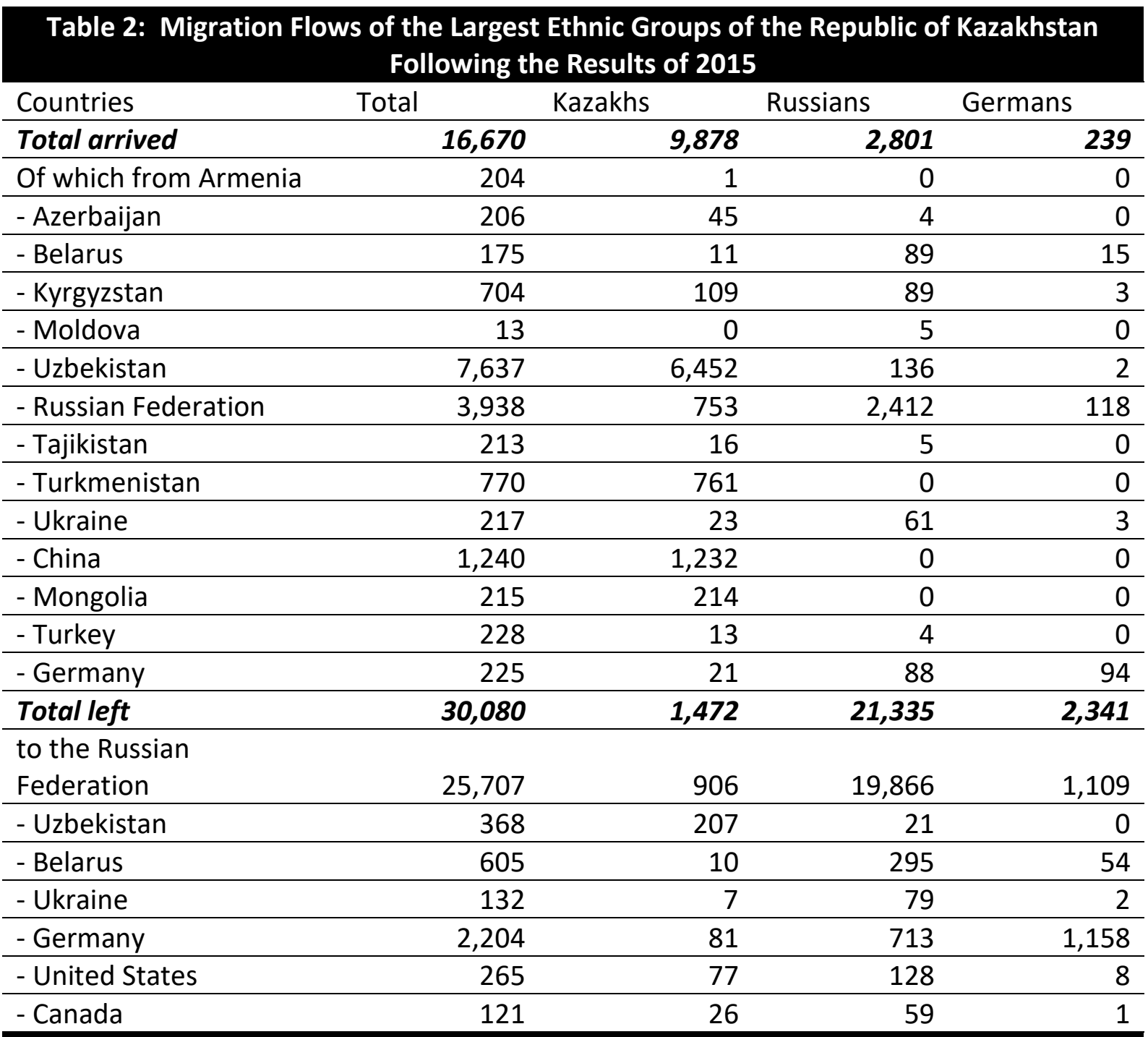

Source: Collected by the author

The ethnonational structure has changed following the growth of the emigration flows of the non-Kazakh population and the repatriation of Kazakhs from Mongolia, Uzbekistan, China and Russia (Kharchenko 2014). The number of the title ethnic group - the Kazakhs - has increased from 6,534 thousand people to $11,748.2$ thousand people, or by $79.8 \%$ in 26 years. This trend is caused not only by natural growth but also by the activation of migration processes. Spontaneous repatriation of ethnic Kazakhs to their homeland began in 1991. The state program Nurly Kosh (Light Overnight Stop) was adopted in 2008 to streamline the process of settlement of ethnic immigrants on the territory of the Republic of Kazakhstan.

This program has become an incentive for many ethnic Kazakhs to return to their ancestral territory. 260,325 families or 955,894 ethnic Kazakhs returned to their ancestral territory and gained the status of repatriates from 1991 to 2015, which amounted to 5.5\% of the total population of the country (Migration situation in the Republic of Kazakhstan for 2015). Most ethnic Kazakhs (61.6\%) arrived from Uzbekistan, 14.2\% from China, 9.2\% from Mongolia, $6.8 \%$ from Turkmenistan and $4.6 \%$ from the Russian Federation. The remaining $3.7 \%$ of the repatriates arrived from other far overseas countries.

The largest number of Turkic ethnic groups is concentrated in the southern regions of Kazakhstan. The Uzbek diaspora is found in the South Kazakhstan region $(87.5 \%$ of the population size of the Uzbek nationality). A large part of the Uighurs is concentrated in Almaty (59.9\% of the size of the ethnic group) and Almaty region $(35.9 \%$ of the size of the ethnic group). 
Unlike the Kazakhs, whose population size increases mainly due to migration growth, the population size of Uzbeks and Uighurs increases mainly due to high birth rates and natural increase. Over the years of independence, Uzbeks (by 216.8 thousand people or 65.3\%), Uyghurs (by 71 thousand people, or $38.3 \%$ ), and Turks (58.4 thousand people, $117.8 \%)$.

Taking into consideration that Uzbek and Uighur diasporas concentrate in the regions that share the borders with the territory of the main settlements of ethnic groups (Uzbekistan and China), threats of territorial claims and demands to form national autonomies may emerge.

The population size of the Russians, Ukrainians, Germans, Tatars, Belarusians, Chechens and Poles demonstrated negative dynamics. A significant decrease in the number of the Russian ethnic group must be noted: over the years of independence, the population size of the Russians declined by 2,583 thousand people, that is, almost by $42 \%$. Their share in the total population of the Republic of Kazakhstan declined from $37.8 \%$ to $20.6 \%$.

Overall, it must be noted that the ethnic structure of the population of the Republic of Kazakhstan has both positive and negative trends. On the one hand, it is preserved tolerance in the mutual relations of the nations living on the territory of Kazakhstan and the loyal state of ethnic policy, while on the other hand, it is activation of the processes of regional identification and socio-economic positioning of ethnic groups, development of external and internal migration (Factors of external influence on interethnic relations in the Republic of Kazakhstan, 2010).

\section{Assessment of the Current Interethnic Situation in the Republic of Kazakhstan}

Public authorities of the Republic of Kazakhstan have always focused their attention on the issues of the establishment of national identity. Under national identity, the feeling of the nation as a whole, represented by original traditions, culture and language, is understood (Definition of National Identity in English, 2015). After the collapse of the Soviet Union in 1991, the ethnically diverse population of Kazakhstan became a challenge to the formation of a new ethnic policy and national identity of the country.

The President of Kazakhstan, Nursultan Nazarbayev, established the idea of interethnic accord back in the early 1990s. Public consent and stability were identified in the Constitution of 1995 as the main principles of the activities of the state. The Basic Law contains over 11 norms that ensure the equality of rights of all citizens regardless of race, ethnicity, religion or social affiliation (Analytics of the Assembly of Peoples of Kazakhstan). A unified civil and public status of ethnic groups is established; their representatives enjoy all of the rights and freedoms of the united peoples of Kazakhstan.

A competent policy allowed the Republic of Kazakhstan to avoid major conflicts and armed confrontations and to maintain socio-political stability in the region. The results of various opinion polls on the problems of interethnic relations demonstrate a high level of tolerance of the population in the republic. For example, according to the results of the opinion poll conducted in 2016 by DEMOSCOPE, 41\% of Kazakhstan respondents describe the relationships as complex but stable, uncritical and largely safe. About $12 \%$ of the respondents estimate the relationship between ethnic groups in the country as "friendly" and troublefree. The rest ascertain a varying degree of complexity of the interethnic interaction of relations. About $28 \%$ of respondents call these relations "complicated, but only at the mundane level, like in any family." Twelve per cent consider the interethnic area "very complicated" and ascertain the deterioration and the possibility of the development of conflicts. The findings of the opinion poll are presented in Table 3. 
Table 3. Findings of the opinion poll on the state of ethnic cohesion in the Republic of Kazakhstan

Questions and options for answers

Number of respondents, people
The number of respondents

1. First of all, I feel as ...

A Kazakhstani. Citizenship and the country are more important than ethnicity and nationality in the passport

The representative of my ethnicity, nationality. Citizenship is secondary to me

Citizenship and nationality are equally important to me 1,117 $35 \%$

Citizenship and nationality are different things. I do not mix them

862

$14 \%$

862

$27 \%$

2. All nationalities (ethnic groups) in Kazakhstan are:

766

$24 \%$

- equal by virtue of law; they are Kazakhstanis in the first place

$59 \%$

- not equal. Despite the Constitution, individual ethnic groups enjoy more or less rights

1,309 $41 \%$

3. Relations between ethnic groups (nationalities) in Kazakhstan are:

\begin{tabular}{lll}
\hline - friendly and trouble-free & 383 & $12 \%$ \\
\hline $\begin{array}{l}\text { - complicated, but only at the mundane level, like in any } \\
\text { family }\end{array}$ & 894 & $28 \%$ \\
\hline - complex but stable, uncritical and largely safe & 1,309 & $41 \%$ \\
\hline - very complex, worsen and can develop into conflicts & 606 & $19 \%$ \\
\hline
\end{tabular}

\begin{tabular}{lll}
\hline 4. For ethnic and religious reasons, I and/or my relatives in Kazakhstan have: & $32 \%$ \\
\hline - never experienced threat and pressure & 1,021 & \\
\hline - rarely experienced threat and pressure, it does not & 1436 & $45 \%$ \\
bother me & 224 & $7 \%$ \\
\hline - experience threat and pressure on a regular basis; & 511 & $16 \%$ \\
\hline - been increasingly facing threats and pressure recently & & 8
\end{tabular}

5. How do you assess the verbal environment in Kazakhstan?

- comfortable. I experience no inconvenience. Everyone understands me, I understand everyone $15 \%$

- satisfactory and stable. Not everyone understands each

other, but it is manageable and non-conflicting

1,404

$44 \%$

- becoming increasingly uncomfortable. The language

issue increasingly causes conflicts

1,309

$41 \%$

6. If relations between ethnic groups in Kazakhstan worsen sharply, it will occur due to

$\begin{array}{lll}\text { - language differences } & 160 & 5 \%\end{array}$

- economic problems. The guilty are usually sought in the crisis

543

$17 \%$

- combination of causes

511

$16 \%$

- only artificially and/or due to provocation/interference

by a third party

1,978

$62 \%$

7. Will you participate in the conflict if it affects the interests of your ethnic group?

\begin{tabular}{lll}
\hline - in no case & 1,963 & $62 \%$ \\
\hline - undecided & 345 & $11 \%$ \\
\hline - it depends on the circumstances & 766 & $24 \%$ \\
\hline - yes, certainly & 118 & $4 \%$
\end{tabular}

\section{Source: DEMOSCOPE, 2016}

Most of the respondents (62\%) believe that interethnic conflicts can arise only for artificially created reasons or in case of provocation or interference of a third party.

According to $17 \%$ of respondents, the economic factor is a major reason for the interethnic conflict. Only $5 \%$ of respondents named language differences in Kazakhstan as a serious conflictogenic basis. A conflictogenic basis is a situation that causes clashes on the basis of 
misunderstanding, rejection of other people's values that arises among people (Khasan and Sergomanov 2001).

Another $16 \%$ of respondents believe that an unfavourable scenario is possible at a combination of the above reasons.

More than half of the respondents (59\%) put civil identity, not ethnicity, first. Civic identity is understood as an individual sense of belonging of an individual to the community of citizens of a particular state (Khasan and Sergomanov 2001). Ethnic identity is understood as a person's consciousness of his belonging to a particular ethnic group (Ryzhova 2011).

Ethnic and civil identities are equally important for $26 \%$ of the respondents. Only $4 \%$ consider themselves representatives of their ethnic group, in the first place. Nineteen per cent are sure that not all citizens are equal, and some ethnic groups enjoy more or less rights. It must be noted that Russians are more critical about the position of their own national group than Kazakhs and other ethnic groups (Simakova 2016). Twice less Russians than Kazakhs feel themselves fully valid citizens of Kazakhstan (41\% against $71 \%$ ), about $15 \%$ of Russians (against $3 \%$ of Kazakh respondents) feel oppression and infringement on national grounds, humiliation of national dignity.

Thirty-two per cent of respondents have never experienced any pressure for ethnic reasons, while $45 \%$ of respondents rarely experienced such a threat, but this fact does not cause concern. Meanwhile, $23 \%$ of the respondents in total noted that they are regularly or increasingly threatened and pressured.

Based on the survey data using the methodology above, the author carried out a quantitative assessment of the current interethnic situation in the Republic of Kazakhstan (Table 4).

According to the findings of the opinion poll conducted by KISS in 2014 (Chernykh 2014), the respondents estimate the level of expectation of interethnic conflict at only $6.3 \%$. The dominant majority of the respondents
(88.2\%) do not expect an open interethnic conflict shortly. The conflict potential on ethnic grounds in Kazakhstan amounted to $27.8 \%$ (25.8\% in 2013).

The above calculations show that the index of ethnic tension is at a low level. Cases of ethnic conflicts and nationalist actions are sporadic today. At the same time, it can be stated that there is latent interethnic tension in the Republic of Kazakhstan.

To assess the changes in the Index of ethnic tension over time, statistical and sociological observations in the area of interethnic relations both across the country and in the context of the regions of the Republic of Kazakhstan must be conducted systematically. However, there is no fully valid system for monitoring and assessing the state of interethnic relations in the country so far.

\section{Issues of Interethnic Relations in the Republic of Kazakhstan}

According to the majority of experts, interethnic contradictions in Kazakhstan are currently inactive and not quite pronounced. At the same time, interethnic incidents in Kazakhstan now happen with frightening regularity. For example, there have been about nine major conflicts on ethnic grounds in the last decade, widely covered in the media.

The key problems in the area of the state of interethnic relations of the Republic of Kazakhstan include:

\section{Insufficiently Efficient Migration Policy.}

Along with the economically positive aspect of attracting legal extra labour resources, the migration process causes changes in the national and cultural composition of the country. Due to a low level of socio-cultural adaptation of migrants to the conditions of the receiving community, a part of the migrants retain socio-cultural behavioural patterns that are characteristic of their traditional places of residence, which contradict the local sociocultural traditions and demonstrate disregard for local cultural traditions and customs. 
Table 4: Assessment of the Current Interethnic Situation in the Republic of Kazakhstan

Indicator

$\begin{array}{ccc}\text { Score } & \text { Share } & \text { Weighted } \\ , \mathrm{Pi} & , \mathrm{ri} & \text { average score }\end{array}$

(\%)

\begin{tabular}{|c|c|c|c|}
\hline All nationalities (ethnic groups) in Kazakhstan are: & & & \\
\hline - equal by virtue of law; they are Kazakhstanis in the first place & 1 & 52 & 0.52 \\
\hline $\begin{array}{l}\text { - not equal. Despite the Constitution, individual ethnic groups enjoy more or less } \\
\text { rights }\end{array}$ & 5 & 48 & 2.4 \\
\hline Indicator $I_{1}$ & & & 2.92 \\
\hline Relations between ethnic groups are: & & & \\
\hline - friendly and trouble-free & 1 & 12 & 0.12 \\
\hline - complicated, but only at the mundane level, like in any family & 2 & 28 & 0.56 \\
\hline - complex but stable, uncritical and largely safe & 4 & 41 & 1.64 \\
\hline - very complex, worsen and can develop into conflicts & 5 & 19 & 0.95 \\
\hline Indicator $I_{2}$ & & & 3.27 \\
\hline I and/or my relatives in Kazakhstan have: & & & \\
\hline - never experienced threat and pressure & 1 & 32 & 0.32 \\
\hline - rarely experienced threat and pressure, it does not bother me & 2 & 45 & 0.9 \\
\hline - experience threat and pressure on a regular basis; & 4 & 7 & 0.28 \\
\hline - been increasingly facing threat and pressure recently & 5 & 16 & 0.8 \\
\hline Indicator $I_{3}$ & & & 2.3 \\
\hline Verbal environment is: & & & \\
\hline $\begin{array}{l}\text { - comfortable. I experience no inconvenience. Everyone understands me, I } \\
\text { understand everyone }\end{array}$ & 1 & 15 & 0.15 \\
\hline $\begin{array}{l}\text { - satisfactory and stable. Not everyone understands each other, but it is } \\
\text { manageable and non-conflicting }\end{array}$ & 3 & 44 & 1.32 \\
\hline $\begin{array}{l}\text { - becoming increasingly uncomfortable. The language issue increasingly causes } \\
\text { conflicts }\end{array}$ & 5 & 41 & 2.05 \\
\hline Indicator $I_{4}$ & & & 3.52 \\
\hline Will you participate in the conflict if it affects the interests of your ethnic group? & & & \\
\hline - in no case & 1 & 61.5 & 0.615 \\
\hline - undecided & 2 & 10.8 & 0.216 \\
\hline - it depends on the circumstances & 4 & 24 & 0.96 \\
\hline - yes, certainly & 5 & 3.8 & 0.19 \\
\hline Indicator $I_{5}$ & & & 1.98 \\
\hline$I_{E T}$ & & & 2.80 \\
\hline
\end{tabular}

Source: Collected by the authors

\section{Imperfection of the Language Policy}

Imperfection of the language policy is perhaps the most important reason for interethnic tension in Kazakhstan's society. In numerous publications, various authors express dissatisfaction with the deplorable state of the Kazakh language (this is how the state of the official language is usually described) (Beisembayev 2015). On the one hand, the state is accused of the insufficient attention to the problems of the development of the Kazakh language; the Russian-speaking population is accused of its ignorance. On the other hand, contrary to the policy declared at the national level, which guarantees access to information in Kazakh and Russian languages, the rights of the citizens can be infringed on a language basis at the local level - there have been cases of refusal to provide services in Russian. 
Social Inequality of the Population in the Republic of Kazakhstan

Such factor as social inequality of the population of Kazakhstan can have a negative impact on the indicator of ethnic intolerance and exacerbation of interethnic relations. According to official statistics, the figures of inequality in Kazakhstan consistently decline (Commission on Human Rights under the President of the Republic of Kazakhstan Analytical Report 2017). However, these indicators do not reflect the real state of affairs in regional income differentiation, which sometimes has a diametrically opposite character (Zhusupova 2015). According to A. Koshanov, the head of the Center for the Theory of Socially Focused Economics of the Institute of Economics of the Ministry of Education and Science of the Republic of Kazakhstan, the "decile coefficient" reflecting the difference in income of the rich and poor social classes in Kazakhstan reaches 29 times, while the indicator in developed countries is about 4.8 times (Exchange leader).

Social inequality has a direct impact on the growth of crime and exacerbation of interethnic conflicts. Observations of the development of ethnic civil unrest reveal that they develop under a common scenario: domestic crime is followed by clashes between representatives of various nationalities. They differ only by one of the participating parties: the Kazakhs get clashed with the Kurds, Uzbeks and Chechens; conflicts occur mainly in the southern and western regions of the republic.

At the same time, the efficiency of the state policy in the field of ensuring interreligious accord must be noted. Considering that religious conflicts are among the reasons for the aggravation of the interethnic situation and Kazakhstan is a country where representatives of various religions coexist, the authorities of the Republic of Kazakhstan pay special attention to the issues of strengthening the stability in the field of religion.

Creation of a separate state body - the Ministry for Religious Affairs and Civil Society of the Republic of Kazakhstan - in 2016 was a timely step determined by the need to form a united civil society. The main task of the newly created state agency is to support the constitutional rights of citizens of the Republic of Kazakhstan in the field of freedom of belief.

The civil servants specialising in migration issues, interethnic relations, and employment policy must be regularly trained and retrained to eliminate the above problems in the field of interethnic relations in the Republic of Kazakhstan. An indispensable condition for the adequate management and regulation of interethnic relations is a systematic assessment of interethnic tensions in the regions of the Republic of Kazakhstan. This requires regular monitoring of the migration and demographic situation, the state of the social infrastructure, the social mobility of the population, employment and unemployment, public sentiments and prejudices, as well as interethnic relations.

\section{The Developing Mechanisms for Prevention of Interethnic Conflicts in the Republic of Kazakhstan}

Despite the fact that the situation in the ethnonational field of the region is described as stable, the ethnic diversity of the population of the Republic of Kazakhstan required further development and implementation of measures aimed at harmonising interethnic relations on the territory of the country.

Back in 2010, the Doctrine of National Unity was developed on the instructions of the President of the Republic of Kazakhstan, which offered a civilian basis to unite the people of Kazakhstan. However, this document was criticised by nationalist movements ("Ult Tagdyry", "Mamlekettik til"), who believed that the ethnic identity of the Kazakhs was blurred in the Doctrine.

In response, the national Social Democratic Party, Azat and the opposition party Ak Zhol presented their "Concept of the National Policy of the Republic of Kazakhstan". This conceptproposed to highlight and focus on the development of ethnic identity, that is, recognition of the Kazakh nation as a key, state- 
forming nation, while other groups of nationalities were supposed to line up behind it.

New opportunities and mechanisms for strengthening the unity and harmony are revealed in the "Concept of strengthening and development of Kazakhstan's identity and unity" adopted in December 2015 (via a decree of the President of the Republic of Kazakhstan No. 147 dated 28 December 2015). The essence of the concept, expressed in the principle of civil equality, is absolutely valid and meets the interests of entire multinational Kazakhstan.

The National Patriotic Idea, Mengilik El is one of the mechanisms for implementing the concept in terms of preventing conflict and creating a stable interethnic situation. ang The main contours of Mengilik El are: civil equality, diligence, honesty, a cult of learning and education. All these will perhaps transform the country into a secular one that might increase tolerance Indeed, this National Idea of Mengilik El based on national values created by the Kazakh people, was presented in the Patriotic Act, adopted on 26 April 2016 at the XXIVth Session of the Assembly of the People of Kazakhstan, "Independence. Harmony, Nation of the United Future." The existing international experience in the formation of national ideas and patriotic pacts should be noted. So, for example, the Japanese success is still associated with the idea of Kaizen - the desire for continuous improvement (Maurer 2015). In various countries, there are various National Ideas - Pancha Shila in Indonesia (Syamsuddin 2015), Rukunegara in Malaysia (Rukunegara: The national ideology of Malaysia, n. d.), socialism with Chinese characteristics in the PRC (Socialism With Chinese Characteristics, n. d.; Jambul liberated, n.d.).

The National Idea found a wide response from the citizens of the country; the creative community, scientists and representatives of the NGOs joined in the promotion and explanation of this idea to the population.
Important priorities of the national policy in the field of stabilisation of interethnic relations, strengthening of mutual understanding and prevention of interethnic conflicts in the Republic of Kazakhstan include:

- Measures to Strengthen the Unity of the Multinational People

- Improvement of Migration Situation Development Mechanisms

- Steps to Decrease Social Inequality

\section{Steps to Enhance the Unity of Multinational People}

A set of analytical and organisational measures is required as a part of strengthening the unity of the multinational people of the Republic of Kazakhstan. For example, organisation and systematic monitoring of interethnic relations in the country in general and in certain regions of Kazakhstan, the formation of a database on religious, national organisations operating on the territory of the Republic of Kazakhstan. It makes sense to generalise the practice of applying the legislation of other countries in the area of regulation of interethnic relations and make proposals for regulation of national legislation in this field.

Measures of state support for the activities of socially-oriented non-commercial organisations that implement patriotic projects promoting the establishment of civil responsibility and ethnic tolerance in the Kazakh society can contribute significantly to solving the tasks of strengthening the unity of a multinational country.

A set of measures aimed at preserving interethnic peace and harmony includes ethnographic expeditions to study the culture of the peoples of Kazakhstan, holding national holidays and parties of the creative Kazakh community with summing up the results of the interethnic friendship, inviting the representatives of all existing national and cultural autonomies.

In order to build civic consciousness and foster a culture of interethnic relations, it is suggested to develop optional classes to study the culture, traditions, and customs of different peoples 
living on the territory of the country, and introduce them into the curriculum of educational institutions. Teaching tolerance classes and holding activities promoting the state symbols of the Republic of Kazakhstan in educational institutions will contribute to strengthening the civil identity of the country's population.

One of the efficient tools of harmonising interethnic relations is an information campaign using modern information technology, the internet, printed and electronic media, as well as social media.

It is proposed to engage migrant children in festivals, competitions, exhibitions, and events dedicated to the memorable dates and state holidays of Kazakhstan, as part of measures to strengthen the foundations of civil society and patriotic education of the population of the Republic of Kazakhstan.

\section{Improving the Mechanisms for Development of the Migration Situation}

the

Ensuring the safe living conditions to the citizens of the Republic of Kazakhstan, the observance of the rights of foreign citizens and the preservation of political and social stability in society are among the most important tasks of the authorities. Illegal migration is one of the sources of destabilisation and increased social tension. The large-scale influx of people from other countries carries major risks for the receiving country: it contributes to the growth of social tension, the emergence of conflicts on ethnic and religious grounds, preservation of threats to national security and public order.

At present, the state authorities of the Republic of Kazakhstan are implementing a set of administrative and legal measures aimed at identifying, suppressing, and eliminating violations of migration legislation. For example, changes have been made in the legislation regulating the procedure for issuing and extending permits to hire foreign labour as an in-company transfer, new rules for temporary registration of citizens at the place of residence have been introduced.
Introduction of a system of selective migration mechanisms can be one of the most promising areas for stabilising the interethnic situation. Selective migration policy in favour of the immigration of highly qualified specialists is becoming increasingly popular among governments all over the world (Kuboyama, 2008; European Commission, 2014).

Instead of spending administrative and financial resources on limiting and preventing the stay of migrants who are unprofitable for the state, they allocate their resources to the creation of conditions and maximisation of raising labour resources, which are useful to the economy, from other countries. Regulation of migration flows transforms from the plane of ensuring security into the plane of increasing economic benefits of the receiving state.

Two competing models of attracting labour migrants are widely used in the migration policy of countries with the developed industrial economy: a scoring system and a system of selection based on applications from employers. Each of the selection systems includes five main criteria for the selection of migrants: the applicant's education, experience, the scope of activities, language proficiency and age, availability of close relatives in the country of arrival.

Immigration regimes following the admission of immigrants based on the scoring system admit immigrants, whose skills and qualifications meet certain requirements, including language proficiency, experience, education and age. The scoring system for the selection of migrants is used in the UK, Singapore, New Zealand, Australia, Hong Kong, etc. Aside from explicit economic benefits, the scoring system introduced in the countries has a positive effect on the socio-political situation in the receiving country.

Thus, the selection criteria that are determined by the needs of the society and the economy provide local citizens with a clear understanding of the need to attract foreigners and inspire confidence in migrants; an understanding emerges that the arrived 
foreigners strengthen the economy of the country, making it stronger.

The system of selecting applications from employers relies on the definition of a specific need for foreign labour and is based on the selection of employees by employers. This selection system is used in Sweden, Spain, the USA, and Norway. Unlike the scoring system, which is largely aimed at the selection of highly educated employees who enter the general national labour market, this system is aimed at meeting the actual labour needs of the enterprises. This system allows employers to independently and in real time determine which qualifications and skills they need in employees. At the same time, the state sets a number of general parameters for selection.

Both systems of the migration selection have certain benefits and drawbacks, and none of them in pure form can fully satisfy the demands of the country interested in selective immigration.

It seems feasible to examine the possibility of creating a selective (combined) migration system, where, on the one hand, the priority is given to satisfying the needs of national employers, while on the other hand, score tests or another set of criteria are used to differentiate applicants of different qualifications.

In general, a good system for selection clear bearing mechanisms for ensuring predictable results that would satisfy all the parties must be adopted. This requires the political will and readiness of the administrative power to introduce these mechanisms and rules. An example of this type of migration system is the Canadian selection system. For the most effective selection by the service of Citizenship and Immigration Canada $(\mathrm{CIC})$, the Express Entry program has been developed, which is used to manage applications for permanent residence falling under federal immigration programs. To identify the chances of successful integration into the Canadian society, a Competitive Ranking System (CRS) was developed. From the point of view of introducing a selective migration system,
Atlantic Immigration Pilot Project is of interest, within which a new mechanism for attracting international students and qualified foreign workers has been launched to fill vacancies in Canada.

For immigration to Canada via Atlantic Immigration Pilot Project, one needs to:

- Get a job offer. The job offer must be from an employer in the Atlantic Provinces (New Brunswick, Newfoundland and Labrador, Nova Scotia, or Prince Edward Island), and only full-time (at least 30 paid hours per week) and off-season.

- Meet the qualification requirements for work experience, education, ability to communicate in English or French, and also to prove financial solvency for self and family support within the initial immigration time.

The sum of points is found depending on the answers in the profile of potential immigrants. The maximum amount is 1,200 points, of which 600 refer to the base part and 600 to the additional one. The basic part includes assessments for professional skills, education, the possibility of using knowledge in Canada, and the likelihood that the applicant's husband/wife will also be able to benefit the new country. Additional 600 points are awarded for the Canadian degree, higher education or certificates; a valid job offer; nomination from a province or territory; a brother or sister residing in Canada; good knowledge of French. Moreover, additional points are awarded to international international students studying in Canada.

It should be borne in mind that the availability of a contract for a job offer is not a mandatory requirement for ITA, but has been and remains an important factor in selection. Candidates who have such a contract backed by the Labor Market Impact Assessment (LMIA) receive additional points, which give them a huge advantage over other candidates. 
- Receive an assessment of needs and a settlement plan. The provider of immigration settlement services conducts a needs assessment and develops a settlement plan for a potential migrant and every adult member of his/her family. Such a plan helps the migrant settle in Canada; contains information about the community where he/she lives, as well as where the migrant and his/her family can get help or support (Express Entry 2017).

- Obtain approval of the Atlantic Provinces. A copy of the settlement plan is sent to the employer who made the job offer. If the province supports the job offer, it sends a letter to the candidate with approval, and he/she receives the Certificate of Approval.

\section{Measures to Reduce Social Inequality}

Measures to reduce social inequality of the population of the Republic of Kazakhstan can be one of the efficient mechanisms for preventing interethnic conflicts. It implies the implementation of a set of measures aimed at creating conditions for social employment of the population of Kazakhstan, eliminating social inequality, stable growth of income, and improving the living standards of households.

It is required to make assessments and to take into consideration the influence of economic policy measures on the social sphere, as well as to conduct an open dialogue with the public on the efficiency of solutions that contribute to equality and economic growth. The official inclusion of tasks to reduce social inequality and inclusion of relevant indicators, in particular, the Gini coefficient, in the national strategy of development of the Republic of Kazakhstan can be the first step.

Mechanisms for supporting the creation of new jobs with adequate remuneration, good career prospects, and opportunities to overcome poverty must be developed.

Taking into consideration the best world practices, the authorities of the Republic of
Kazakhstan need to develop additional measures to maximise the number of lowincome citizens covered by the state social assistance under a social contract and expenditures of regional budgets for these purposes. It is suggested to expand the list of measures for promoting the employment of parents, including women on three years' parental leave, develop flexible forms of employment, ensuring proper conditions for looking after and caring for infants, fostering and educating children in the family.

It seems necessary to develop methodological recommendations for assessing the need and to set criteria of the need in the provision of social support to the population of the Republic of Kazakhstan by public authorities.

\section{Conclusion}

The conducted study allows to state that the current ethnic composition of the population of the country experiences the direct impact of migration processes. Formula tools for calculating the Index of Ethnic Tension ( $\left.\mathrm{I}_{\mathrm{ET}}\right)$ were presented during the preparation for the empirical study. This indicator allows to bring the results of the opinion polls to a standard form and will allow conducting a comparative analysis of the interethnic situation in the context of the regions of the Republic of Kazakhstan. The consistent accomplishment of the tasks of the study in this paper allows the author to formulate the following conclusions:

- The Republic of Kazakhstan is described as a multiethnic country by the composition of the population. At the same time, migration processes in combination with demographic processes have a significant impact on the ethnic structure of the Republic of Kazakhstan. The share of Kazakhs has significantly increased over the years of independence, and now it is the main ethnic group that makes up two-thirds of the population of the country. At the same time, the share of the Russians in the ethnic structure is steadily declining, despite the fact that they are the 
- second largest ethnic group in the Republic of Kazakhstan. Although the headcount and share of the Russian population still remain at an acceptable level, there is an advancing decline in the level of its social activity and cultural leadership.

- Since interethnic contradictions in Kazakhstan are inactive, the situation can be described as moderately tense. Although the index of ethnic tension is at a low level, there remains a risk of ethnic conflicts and individual nationalist actions.

- The conducted study allowed to identify key problems influencing the growth of contradictions and tension in society: insufficiently efficient migration policy, imperfect language policy, deepening social differentiation of the population.

- The results of the conducted study allowed to outline promising directions of the state policy on stabilising interethnic relations and strengthening the national and civil unity of the population of the country. These areas include a set of measures to strengthen the unity of the multinational people of the Republic of Kazakhstan, improvement of the mechanisms for the development of the migration environment, and measures to reduce social inequality.

\section{References}

Assyltaeva, E., Z. Tolen and G. Nassimov (2014). Kazakhstan as a model for regulating interethnic relations, Procedia - Social and Behavioral Sciences, 114, pp. $291-297$

Aubakirova, S. S., et al. (2016). Tolerance issue in Kazakh culture, International Journal of Environmental \& Science Education, 11(12), pp. 5034-5048

Beisembaev S. (2015). Fenomen kazakhskogo natsionalizma $v$ kontekste segodnyashney politiki: ot otritsaniya $k$ ponimaniyu [Phenomenon of Kazakh nationalism in the context of contemporary politics: from denial to understanding]. Program for young researchers in the field of public policy by the Soros Foundation in Kazakhstan. Available at:http://ru.soros.kz/uploads/user_68/2015 _23_09_03_46_44_219.pdf (accessed on 10 February 2017).

Borangaliev, A.M. (2010). Problems of external labor migration in Kazakhstan at the present stage. Kazakhstan-Spectrum, 2, pp. 66-71.

Bureau of express monitoring of public opinion DEMOSCOPE (2016, 15 August). The poll "On the state of ethnic cohesion in the Republic of Kazakhstan." Available at: http://www.demos.kz/rus/?poll=53 (accessed 5 January 2018)

Chernykh I.A. (2014). Kazakhstan v 2013 godu: aktualnyye voprosy razvitiya strany cherez prizmu obshchestvennogo mneniya [Kazakhstan in 2013: topical issues of the development of the country through the prism of public opinion]. Almaty: KISS under the President of the Republic of Kazakhstan, pp. 127-163.

Collection of International and National documents on the issues of combating trafficking in persons. (2011). Almaty: IOM

Commission on Human Rights under the President of the Republic of Kazakhstan analytical report (2017). Current problems in the protection of the rights of migrant workers and victims of trafficking in persons in the Republic of Kazakhstan. In K. Sultanov and T. Abishev (eds). Astana, pp. 179.

Definition of National Identity in English. Oxford Dictionaries. Archived from the original on 17 November 2015.

Express Entry (2017). Information resource. Life in Canada.RF. Available at: https://жизнь-вканаде.рф/иммиграция/express-entry/ accessed 5 January 2018)

European Commission, (2014). Communication from the Commission to the European Parliament and the Council on the implementation of Directive 2009/50/EC on the conditions of entry and residence of third-country nationals for the purpose of 
highly qualified employment, COM(2014)287final, 22.5.2014, Brussels

Factors of external influence on interethnic relations in the Republic of Kazakhstan: collective monograph. (2010). Almaty: KISI under the President of the Republic of Kazakhstan, pp. 112.

Gurieva, S.D. (2010). Psychology of interethnic relations. St. Petersburg: Publishing house "VVM.", pp. 278.

Jambul liberated. Why are ethnic conflicts denied in Kazakhstan? Central Asian Portal Available at: http://www.caportal.ru/article:25708 (accessed January 5, 2018)

Kharchenko, S.V. (2014). Interethnic relations in Kazakhstan: historical heritage and the current state, Sociological research, 2, pp. 55-58.

Khasan, B.I. and P.A. Sergomanov (2001). Conflict resolution and negotiation: workbook. Krasnoyarsk; Moscow: Institute of Psychology and Education Pedagogy of RAO UES.

Kydyralina, Zh.U. (2012). Ethnopolitics of sovereign Kazakhstan, History of the state, 4, pp. 5-26.

Kuboyama, R. (2008). The Transformation from restrictive to selective immigration policy in emerging national competition state: Case of Japan in Asia-Pacific Region. Working Paper 61/2008, Bielefeld: COMCAD - Center on Migration, Citizenship and Development, Bielefeld University.

Lisitsyn, P.P. (2017). Boundaries and content of the migration process: a theoretical definition and operationalization of objects of migration research, Monitoring of public opinion: Economic and social changes, 1, pp. 11-28.

Maurer, R. (2015). One small step can change your life: The Kaizen way. Moscow: Alpina Publisher, pp. 192.

Melich, J. and A. Adibayeva (2014). Nationbuilding and cultural policy in Kazakhstan,
European Scientific Journal, 2, pp. 265-279. (ISSN: 1857 - 7881)

Mukhamedzhanova, DSh. (2011). Kazakhstan and international integration processes: monograph. Almaty: KISI under the President of the Republic of Kazakhstan, pp. 200.

Nurgalieva, M. (2013). Reserves and risks of interethnic stability in Kazakhstan (based on the results of monitoring "Social sentiments in major cities of Kazakhstan" for 2012). National consolidation of Kazakhstan: problems and prospects: Collection of materials of the round table. Almaty: IFPR of the Ministry of education of the RK, pp.196.

Papadimetriou, D.G. and M. Sampson (2011). Revision of the point system and the system of applications from employers. Washington, DC: Institute for Migration Policy.

Ravenstein, E.G. (1885). The Laws of migration, Journal of the Statistical Society of London, 48(2), pp. 167-235

Rukunegara: The national ideology of Malaysia. Available at: https://www.jpnin.gov.my/ (accessed January 5, 2018)

Rustembekova, D.K. and S.K. Amandykova (2014). Some questions of political and legal basis of interethnic relations in Kazakhstan, KazNU Bulletin. Law series, 1 (69), pp. 93-98

Ryzhova S.V. (2011). Ethnic identity in the context of tolerance. Moscow: Alfa-M, pp. 280.

Sadovskaya, E. Yu. (2001). Migracii v Kazakhstane na rubezhe XXI veka: novye tendency i perspektivy [Migration in Kazakhstan at the turn of the XXth century: new trends and prospects]. Almaty: Gylym, pp. 236.

Schatz, E.A.D. (2000). Framing Strategies and Non-Conflict in Multi-Ethnic Kazakhstan, 6 Nationalism \& Ethnic Pol., 71, pp. 77-78

Simakova, O. (2016). Emigratsiya russkikh: priglasheniye $\mathrm{k}$ razmyshleniyu [Emigration of the Russians: an invitation to reflection]. 
Kazakhstan Spectrum. Scientific journal, 75, pp. 99-109.

Smagulova, J. (2006). Kazakhstan, Innovation, 19, pp. 303-320.

Socialism With Chinese Characteristics.

Available at:

at: https://www.tumblr.com/search/Socialis $\mathrm{m}+$ with+Chinese+characteristics (accessed 5 January 2018)

Syamsuddin, M.M. (2015). Indonesian philosophy: its meaning and relevance in the context of Asian countries development, International journal of the Asian Philosophical association, 8(2), pp. 201-214

Tishkov V. (1997). Ethnicity, nationalism and conflict in and after the Soviet Union. SAGE Publications Ltd. Available at: http://sk.sagepub.com/books/ethnicity- nationalism-and-conflict-in-and-after-thesoviet-union (accessed January 5, 2018)

Titova, T.P. (2015). Highly qualified specialists as a category of labor migrants: identification problems in selective immigration policy of foreign countries, Sociological Almanac, 2015, pp. 142-150.

Yesimhanova, N.I. (2014). Ethnocultural development of the Republic of Kazakhstan. Tutorial. Arkalyk.

Zhusupova, A. Dinamika sotsialnogo neravenstva $v$ Kazakhstane [Dynamics of social inequality in Kazakhstan]. Institute of the World Economy and Politics (IWEP) under the Fund of the First President of the Republic of Kazakhstan, the Nation Leader. Astana - Almaty: Institute of the World Economy and Politics, pp. 18. 